\title{
Teachers' Views on the Use of Mobile Phones in Schools
}

\author{
Turgay ALAKURT*1 (D) Burcu YILMAZ² (D) \\ ${ }^{1}$ Kütahya Dumlupınar University, Faculty of Education, Kütahya, Turkey, turgay.alakurt@dpu.edu.tr \\ 2 The Ministry of National Education, Ankara, Turkey, burcuyilmaz.mail@gmail.com \\ * Corresponding Author: turgay.alakurt@dpu.edu.tr
}

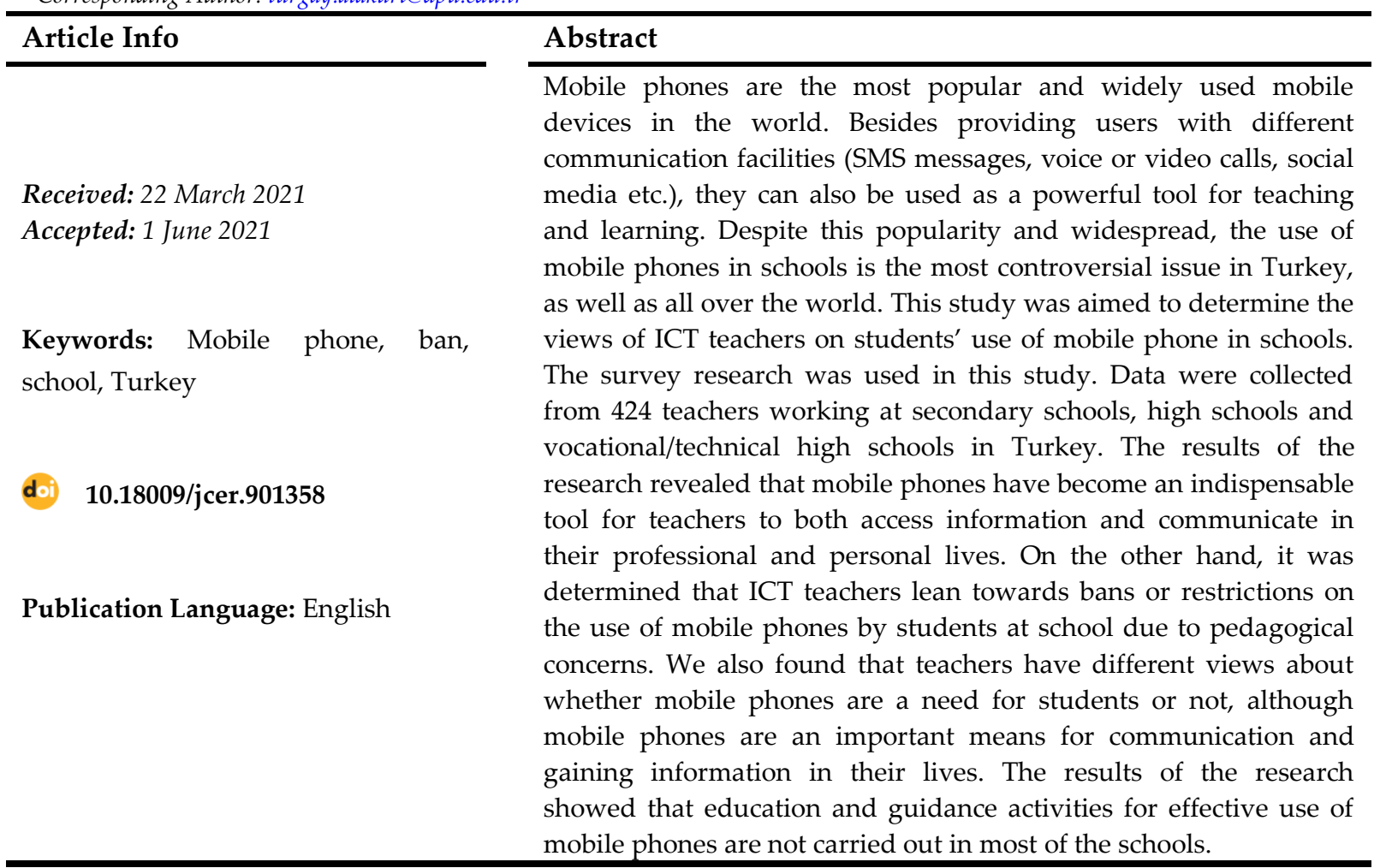

open access $\square$ Crossmark (C)

To cite this article: Alakurt, T. \& Yilmaz, B. (2021). Teachers' views on the use of mobile phones in schools. Journal of Computer and Education Research, 9 (18), 575-597. DOI: 10.18009/jcer.901358

\section{Introduction}

The use of mobile technologies in education environments by students of different age groups has been on the rise (Sundgren, 2017; Walker, 2013). With the transition to mobile economy, recently launched policies at schools such as Bring Your Own Device (BYOD), Bring Your Own Technology (BYOT), and 1:1 Tablets have become more and more popular as part of a new transformation in education. In the report prepared by European Schoolnet, BYOD (or BYOT) denotes allowing the employees (school administrators, teachers, etc.) or students to bring their personal mobile devices to their workplace or education centers and use these devices to access institutional (or other) information, applications, and services 
(Attewell, 2015). It is also used to define a concept that includes a new generation study habit (Esmeray, 2018).

Pointing at the increase in the number of studies on BYOD in higher education since 2007/2008 in which iPhone and Android phones started to emerge, Sundgren (2017) indicates that studies focus more and more on the learning opportunities provided by the mobile devices and the learning activities that can be conducted with mobile devices as their specifications and capacities increase. Examining the mobile device use of 14-16-year-old students, Walker (2013) similarly expresses that students benefit educationally from using mobile devices and that students believe that these devices facilitate their learning. He also notes how students have found creative ways of using several specifications of these devices in schoolwork, which are grouped under five categories, namely, the Internet, organizational tools (calendar, alarm, etc.), audio-visual tools (camera, voice recorder, etc.), learning tools (mobile apps, iTunes, etc.), and communication tools (social media, SMS, etc.). European Schoolnet summaries the uses of BYOD for schools under four headings: (1) increasing the quality and efficacy of teaching and learning, (2) increasing the sustainability and efficiency of learning in technologically enriched learning environments, (3) providing organizational benefits, and (4) improving family participation (Attewell, 2015). In the same vein, the report prepared by McKinsey and Company (2012) is noteworthy to provide an extensive foresight regarding the global use of mobile technologies in education in the future. Similarly, Winters (2013) indicates that this report is important to understand how the mobile communication industry can support mobile learning. Given the importance and effect of learning taking place outside of traditional class environments, the report emphasizes that the transformative power of mobile technologies for education should not be underestimated, and it brings forth "mEducation" which represents a profound change in the way education is given and received. mEducation is defined as a new way that enables access to technologybased learning solutions and educational content through such tools as laptops, phones, and tablets by wireless and mobile communication systems. There are three distinct advantages provided by mEducation, which denotes technology-aided learning solutions which teachers and students can use anytime, anywhere (McKinsey \& Company, 2012):

- It overcomes traditional time, location and collaboration constraints by simplifying access to content and experts. 
- It personalizes education solutions for individual learners, helps educators customize the teaching process, uses software and interactive media that adapt difficulty levels to students' understanding and pace.

- It addresses specific challenges that reduce the efficiency of educational systems around the world.

Today's education systems have started to transform themselves in the light of the vision put forth by McKinsey \& Company. In Spain, for instance, a multifaceted mEducation program called mSchools (see https://mschools.mobileworldcapital.com/) initiated in 2012 by Mobile World Capital Barcelona, which has dedicated itself to the mobile and digital transformation of society, is a noteworthy project. It brings together the public and private sectors to prepare students to the contemporary digital world and help them develop new skills. There are three focal points of the project: to improve learning by using mobile technologies, to promote digital proficiencies and entrepreneurship, and to construct a mEducation-friendly learning environment (Calabuig \& Palacin, 2016). The program also contains 10 different initiatives to give teachers the opportunity to use mobile devices in schools and to motivate students to learn using mobile technologies (mSchools, 2020). These initiatives are as follows:

- Mobile History Map: A geo-positioning app that allows students to collaboratively create content on points of interest close to their school.

- Mobile Learning Awards: Award event honoring innovative teachers and school-led projects for their use of mobile technology in education.

- Changing Education Together: Annual events bringing together decision makers, educators and industry representatives.

- App Education: High school level elective course focusing on developing apps for mobile devices, encouraging teamwork and introducing entrepreneurial spirit to students.

- Student Awards: Competition and award ceremony organized to celebrate teachers and students for their accomplishments in the mSchools programme.

- Scratch Challenge: Modular course that focuses on the development of computer thinking skills in the classroom by learning the Scratch program.

- TechCamp: Summer camp combining outdoor team building activities with digital design and development. 
- ToolBox: Online repository containing validated and tested mobile education content for schools, teachers, parents and students.

- EduHack: Program that encourages teachers to develop innovative classroom experiences for all classes and subjects using digital technology.

- mSTEAM: Teaching modules that bring mobile technology closer to the STEAM curriculum.

The use of mobile devices with different specifications at different price segments has been steadily on the rise in Turkey, just like the rest of the world. According to the "Survey on Information and Communication Technology (ICT) Usage in Households and by Individuals" shared by Turkish Statistical Institute (TurkStat), mobile phone/smart phone use is in first place with a strikingly high percentage (99.42\%) across Turkey. This is followed by laptops (36.42\%) and tablets (21.99\%). On the other hand, the use of desktop computers has shown a downwards trajectory since 2010, and it has dropped off to 16.74\% (TurkStat, 2020). Deloitte's (2019) Global Mobile Consumer Survey conducted in 28 countries on six continents also put forth similar results about Turkey. With adults aged 18-50, the study indicated that $90 \%$ of the participants from Turkey have mobile phones, $76 \%$ have laptops, and $59 \%$ have tablets. The use of smart watches is around $22 \%$. In the report, it was stated that mobile phones have become indispensable items everywhere including Turkey for individuals compared to other mobile devices in all demographics, age, and income groups. This shows that mobile phones are the most widely used mobile devices. However, despite this widespread use, there have been intense discussions in Turkey, as well as other parts of the world, whether to allow their use in classrooms. School administrators, teachers, students, and parents, all of whom are stakeholders in education, having different demands and expectations and projects offering rich and innovative ways to access technology-based learning solutions such as mSchools or new school policies such as BYOD fuel these discussions.

Regulations for Using Mobile Phones in Schools Around the World

In England, where one of the most intense debates on the issue takes place, schools are free to determine their own rules although there is no official ban. According to the Ministry of Education, 95\% of schools in England somewhat control the use of phones in schools (Wright, 2018). With the law passed in 2018, the use of mobile phones during school hours at schools was banned for students aged 3-15 in France. How the mobile phone ban 
can be employed in high schools with students over 15 was left to schools themselves (Smith, 2018). In Victoria, one of the six states of Australia, mobile phone use of primary and secondary school students during school hours beginning with the first semester of 2020 will be banned ("Mobile phones", 2019). Similarly, the Western Australian government decided to ban students' use of mobile phones in all state schools. The law, which came into force in 2020, limits students use of mobile phones, smart watches, tablets, and headphones unless it is by the instruction of a school personnel ("Mobile phones to be banned", 2019). In Japan, primary and secondary school students were banned from bringing mobile devices to school, and high school students' use was restricted. However, this ban was lifted in 2018 both due to the widespread use of phones and due to security concerns, such as being able to reach a student during an earthquake. According to the new regulations, each school sets its own rules and informs its students about mobile phone use at school ("Tokyo to allow", 2019). In Turkey, on the other hand, essentials concerning the use of mobile phones and other IT tools in Ministry of National Education (MoNE) schools were indicated in the regulations of both Primary Education and Secondary Education Institutions.

\section{Regulations Regarding the Use of Mobile Phones in Schools in Turkey}

“Using IT tools for personal, social, and educational benefits" is among the expected behaviors from students in MoNE's Regulation on Pre-School and Primary Education Institutions (Ministry of National Education [MoNE], 2014), and "keeping one's mobile phone turned on" is cited among the behaviors necessitating admonition. IT tools are defined within Regulation on Secondary Education Institutions. According to this, "mobile phones and cameras with audio and video recording capacities; computers, data storage devices, pagers, and similar devices used for gathering, storing, designing, processing, transferring, and reproducing information" are defined as IT tools. The regulation requires students to use IT tools and social media for personal, social, and educational benefits. Moreover, displaying good behavior is among the requirements of receiving an honor certificate. A new revision done in the Regulation on Secondary Education Institutions (MoNE, 2019) with the amendment published in the official gazette issue 30870 on September 5, 2019 regulated the use of mobile phones in breaks or during classes. Rules and procedures concerning the use of IT tools as class material based on the characteristics of the curriculum and concerning the allowance of possessing and using them in education environments, keeping in mind such circumstances as dormitories and students' special 
needs, were updated. According to this, the possession of such tools in education environments was made dependent on the decree of the board of directors with the following item:

"It is essential that students do not enter education environments with IT tools. However, using IT tools as course material and equipment based on the characteristics of the curriculum, the allowance of possessing and using them in education environments, keeping in mind such circumstances as dormitories and students' special needs, and during class breaks and lunch breaks with the explicit permission of the school administration and with the knowledge and control of the teacher during class hours, possessing and using IT tool in education environments and letting them to be used as well as the rules and procedures concerning these are determined and decreed by the board of teachers, and these decisions are announced to the students and parents (Item, 52/t)."

The item "To behave in a way what will harm or disrupt education processes" in the Regulation can be related to IT tools. In addition, the following behaviors are also listed in the Regulation as actions that would necessitate reprimand:

- Using IT tools disregarding the rules and procedures decreed by the board of teachers.

- Disrupting the flow of the lesson by keeping IT tools on without the knowledge and control of the teacher.

- Possessing IT tools and using them in education environments; possessing and using them during breaks and lunch breaks without the permission of the school administration.

There are different rules and procedures concerning the use of mobile phones in the regulations for primary and secondary education institutions in Turkey. At the secondary education level, permissions, rules, and procedures for students' use of mobile phones are determined and implemented by the board of teachers. At the primary education level, on the other hand, it is underlined that students can use mobile phones without disrupting education processes as long as it is for personal, social, or educational benefit. As can be seen, there are different ways of exercising the use of mobile phones in Turkey as well as in other countries both due to education levels and countries' systems of government. Some countries may opt to ban use while others may elect to limit it. However, the dominant opinion is that the decisions to be made on students' use of mobile phones in schools should be left to schools themselves considering the education levels just like in Turkey. 
Advantages and Disadvantages of Mobile Phones in Schools

Considering the use of mobile phones in classes, research on the pedagogical advantages and disadvantages of these devices is still fairly new and there is no clear consensus on the issue (Baker, Lusk, \& Neuhauser, 2012). There are a number of studies underlining the benefits of using mobile phones in classes as a means of effective learning and teaching (Looi, Sun, \& Xie, 2015; Purcell, Heaps, Buchanan, \& Friedrich, 2013; SmithStoner, 2012; Steel, 2012; Thomas, O’Bannon, \& Bolton, 2013; Yıldırım, Yaşar, \& Duru, 2016; Walker, 2013). On the other hand, discussions laying bare the possible disadvantages of their use highlight these phones being distractive negatively affecting the teaching process (Baker, Lusk, \& Neuhauser, 2012; Campbell, 2007; Lenhart, Ling, Campbell, \& Purcell, 2010; McCoy, 2013; Shelton, Elliot, Eaves, \& Exner, 2009; Thomas, O’Bannon, \& Bolton, 2013; Yıldırım, Yaşar, \& Duru, 2016). In addition to all these, whether mobile phone use has an impact on academic success is another area of contention. In this respect, the meta-analysis study by Kates, Wu and Corny (2018) which aims to put forth to what extent the use of mobile phones affects students' academic success is significant in revealing generalizable finding for secondary school, high school, and university levels. At the end of this study, it was determined that the use of mobile phones has a small negative effect on educational outcomes $(\mathrm{r}=-0.16)$. However, the researchers also warn against jumping to hasty conclusions based on these findings; they maintain that the summary effect size has a relatively small value even in the educational field.

Purpose of the Study

The advantages and disadvantages of using mobile phones in classes are still a subject of debate in literature. While some schools point blank ban the use of mobile phones others implement school policies such as BYOD along with certain restrictions. In many developed and developing countries, students were distributed millions of tablets or laptops keeping in line with “One Laptop Per Child” (Doğan, Çınar, \& Seferoğlu, 2016). In Turkey, thousands of interactive boards were set up in classes and hundreds of tablets were distributed to students through the FATIH project initiated in 2010 to ensure equal opportunity in education and to improve schools' technology. Studies still being conducted within the frame of this project have contributed to strengthening the physical infrastructure of schools. However, it should be kept in mind that besides equipment enhancements, an important component of technological integration in classrooms is the teachers (Akinc1, 
Kurtoğlu, \& Seferoğlu, 2012; O'Bannon \& Thomas, 2015). Within the framework of these policies, the primary source that would decide how to manage teaching processes in accordance with students' needs is the teachers, who are in direct contact with their students in their classrooms. Moreover, there is a gap in literature on teachers' views on the use of mobile phones in schools. For these reasons, it was decided to focus on teachers instead of school administrators, parents, or students. Within the scope of this study, the views of "Information and Communication Technology (ICT) Teachers" on the use of mobile phones was examined. These teachers pioneer the development of a technology culture in the schools at which they work and thus assume a leading role. ICT teachers have assumed an important responsibility in students' developing an awareness for lifelong learning when they guide them in using information technologies appropriately and effectively and in acquiring digital literacy (MoNE, 2018). In addition, ICT teachers assume several roles outside of the responsibilities defined by the Ministry of Education; they help other branch teachers, besides students, in different matters (Topu \& Göktaş, 2012). In this respect, research questions guiding this study are as follows:

1. What are the preferred means of ICT teachers to access information?

2. What are the ICT teachers' use of mobile phones for communication with colleagues, parents and students?

3. Do ICT teachers' views about the impacts of mobile phone bans or restrictions on educational outcomes in school vary?

4. Do ICT teachers' views about whether the mobile phone is a need for students vary?

5. Do ICT teachers' views about education and guidance activities for effective use of mobile phones in schools vary?

\section{Method}

\section{Research Design}

A quantitative research design guided by the recommendations of Cresswell (2013) was employed to address the research questions. The use of mobile phones by students in schools is a controversial issue. In the present study, we aimed to reveal ICT teachers' views on students' use of mobile phones in schools. The survey model was preferred to investigate 
and describe the views of participants. It helped us to identify important points about mobile phone bans in schools.

\section{Study Group}

A total of 424 ICT teachers from three different grade levels participated in this study by responding to the survey. Within the scope of this study, the views of teachers working in secondary school, high school and vocational/technical high school levels were examined. These groups were preferred because they are at the center of discussions on mobile phone use at K12 level due to the age of the students. Among them, 389 (91.75\%) of the participants work in a public school and $35(8.25 \%)$ in a private school. Out of 424 teachers, $291(68.63 \%)$ of them stated that they were working in secondary school, 78 (18.40\%) in high school, and $55(12.97 \%)$ in vocational/technical high school. All participants are actively engaged in the teaching profession.

\section{Data Collection Tools}

Research data were collected with an instrument specifically designed for this study. This data collection tool was developed by the researchers. We followed the conventional procedure of questionnaire development (Büyüköztürk, 2005). The questionnaire item pool was based on the current and up-to-date literature review associated with mobile phone use in schools. Content and face validity for questionnaire was reviewed by using experts $(n=3)$ in the field of educational technology. We conducted a pilot study with three ICT teachers who have at least 10 years of work experience. They marked information whether it is suitable or not. The questionnaire consists of three parts. In the first part, the participants were asked to rank the means they preferred in accessing information according to their priority. The second part includes questions to determine whether teachers use mobile phones for communication with colleagues, parents and students. With the questions in the first two sections, there is an effort to determine the mobile phone usage habits of the participants. Participants in the study group consist of teachers actively working at public or private schools. In this context, the third part includes questions reflecting teachers' professional knowledge and experiences, and determining the impacts of mobile phone bans or restrictions on educational outcomes in schools. In this section, teachers were also asked whether mobile phones are a need for students and whether education and guidance activities have been carried out in their schools regarding the effective use of mobile phones. While analyzing the questions in the third part, the views of the participants were examined 
in two separate groups. Participants who stated that there are bans or restrictions on the use of mobile phones by students in their school form G1 group, while participants who stated that there are no bans or restrictions constitute the G2 group.

\section{Data Collection and Analysis}

The quantitative data of the study were collected from ICT teachers through an online survey. We utilized the communication channels (Instant messaging apps and social media accounts) of a non-governmental organization which operates in the field of information technologies in Turkey to collect data. LimeSurvey was used to design and implement the survey. An invitation message was sent to participants along with a cover letter to participate in the survey via communication channels. Teachers volunteered to participate in this study. To promote the completion of the survey and increase response rate, we renewed our invitations three times in one-week interval. The approximate time for completion was 10 minutes. The results of the normality test showed that the data was not normally distributed. Therefore, chi-square test, which is a nonparametric statistical test, was employed to analyze the categorical variables. Besides that, descriptive statistics which show the frequency and percentage were also carried out. The data was analyzed using the GNU PSPP 0.8.4 statistical package program.

\section{Findings}

\section{Preferred Means of ICT Teachers to Access Information}

In this study, participants were asked to rank the means they preferred to access information according to their priority status. Primary means preferred by teachers in order to access information according to the school type and grade level are presented in Table 1.

Table 1. Teachers' preferred means to access information

\begin{tabular}{|c|c|c|c|c|c|c|c|c|}
\hline & & & $\begin{array}{l}\text { Mobile } \\
\text { Phone }\end{array}$ & PC & Experts* & $\begin{array}{l}\text { Printed } \\
\text { Sources }\end{array}$ & Colleagues & Total \\
\hline \multirow{4}{*}{$\begin{array}{l}\text { School } \\
\text { Type }\end{array}$} & Public School & $\mathrm{f}$ & 176 & 161 & 21 & 16 & 15 & 389 \\
\hline & & $\%$ & 45.24 & 41.39 & 5.40 & 4.11 & 3.86 & 100.00 \\
\hline & Private School & $\mathrm{f}$ & 13 & 11 & 3 & 5 & 3 & 35 \\
\hline & & $\%$ & 37.14 & 31.43 & 8.57 & 14.29 & 8.57 & 100.00 \\
\hline \multirow{6}{*}{$\begin{array}{l}\text { Grade } \\
\text { Level }\end{array}$} & Secondary & $\mathrm{f}$ & 134 & 113 & 18 & 12 & 14 & 291 \\
\hline & School & $\%$ & 46.05 & 38.83 & 6.19 & 4.12 & 4.81 & 100.00 \\
\hline & High & $\mathrm{f}$ & 38 & 31 & 3 & 4 & 2 & 78 \\
\hline & School & $\%$ & 48.72 & 39.74 & 3.85 & 5.13 & 2.56 & 100.00 \\
\hline & Vocational / Technical & $\mathrm{f}$ & 17 & 28 & 3 & 5 & 2 & 55 \\
\hline & High School & $\%$ & 30.91 & 50.91 & 5.45 & 9.09 & 3.64 & 100.00 \\
\hline
\end{tabular}

*Expert: A person who has lots of knowledge, opinion and skills in a certain job. 
As can be seen in the table, mobile phones (45.24\%) and PCs (41.39\%) are the most preferred means of participants working in the public school to access information. This is followed by consulting experts $(5.40 \%)$, reading printed sources $(4.11 \%)$ and referring to colleagues $(3.86 \%)$. It is seen that the opinions of private school teachers are similar to the views of the public school teachers. Private school teachers mostly prefer mobile phones (37.14\%) and PCs (31.43\%) as their primary means. According to the grade levels, $50.91 \%$ of the teachers working in vocational/technical high schools stated that they preferred PCs as their primary means. On the other hand, secondary (46.05\%) and high school (48.72\%) teachers also indicated that they use mobile phones as a primary means of accessing information.

\section{ICT Teachers' Use of Mobile Phones for Communication}

Findings on the use of mobile phones for communication with colleagues, parents and students were presented in the Table 2. In the following, the findings regarding the school type and grade level were also given.

Table 2. ICT teachers' use of mobile phones for communication

\begin{tabular}{|c|c|c|c|c|c|c|c|c|c|c|c|c|}
\hline & & \multicolumn{10}{|c|}{ Communication Purpose } & \multirow{3}{*}{ 㝘 } \\
\hline & & \multicolumn{4}{|c|}{$\begin{array}{c}\text { Communicate with } \\
\text { colleagues }\end{array}$} & \multicolumn{3}{|c|}{$\begin{array}{c}\text { Communicate with } \\
\text { parents }\end{array}$} & \multicolumn{3}{|c|}{$\begin{array}{l}\text { Communicate } \\
\text { with students }\end{array}$} & \\
\hline & & & $\mathbf{y}$ & $\mathbf{n}$ & $\mathbf{u}$ & $\mathbf{y}$ & $\mathbf{n}$ & $\mathbf{u}$ & $\mathbf{y}$ & $\mathbf{n}$ & $\mathbf{u}$ & \\
\hline School & Public & $\mathrm{f}$ & 387 & 2 & - & 305 & 63 & 21 & 168 & 187 & 34 & 389 \\
\hline \multirow[t]{3}{*}{ Type } & School & $\%$ & 99.49 & 0.51 & - & 78.41 & 16.20 & 5.40 & 43.19 & 48.07 & 8.74 & 100.00 \\
\hline & Private & $\mathrm{f}$ & 35 & - & - & 29 & 6 & - & 14 & 20 & 1 & 35 \\
\hline & School & $\%$ & 100.00 & - & - & 82.86 & 17.14 & - & 40.00 & 57.14 & 2.86 & 100.00 \\
\hline Grade & Secondary & $\mathrm{f}$ & 289 & 2 & - & 234 & 44 & 13 & 99 & 169 & 23 & 291 \\
\hline \multirow[t]{5}{*}{ Level } & School & $\%$ & 99.31 & 0.69 & - & 80.41 & 15.12 & 4.47 & 34.02 & 58.08 & 7.90 & 100.00 \\
\hline & High & $\mathrm{f}$ & 78 & - & - & 56 & 18 & 4 & 42 & 26 & 10 & 78 \\
\hline & School & $\%$ & 100.00 & - & - & 71.79 & 23.08 & 5.13 & 53.85 & 33.33 & 12.82 & 100.00 \\
\hline & Vocational / & $\mathrm{f}$ & 55 & - & - & 44 & 7 & 4 & 41 & 12 & 2 & 55 \\
\hline & $\begin{array}{c}\text { Technical High } \\
\text { School }\end{array}$ & $\%$ & 100.00 & - & - & 80.00 & 12.73 & 7.27 & 74.55 & 21.82 & 3.64 & 100.00 \\
\hline
\end{tabular}

Almost all participants stated that they use mobile phones to communicate with their colleagues. Similarly, the vast majority of public $(78.41 \%)$ and private $(82.86 \%)$ school teachers indicated that they use mobile phones to communicate with parents. However, it is seen that there are different opinions of the participants about using mobile phones for communication with their students. While $43.19 \%$ of the public school teachers stated that 
they use their mobile phones to communicate with their students, this rate is $40.00 \%$ among those working in private schools. When analyzed according to grade levels, it was determined that the rate of using mobile phones to communicate with students was $34.02 \%$ among secondary school teachers, 53.85\% among high school teachers, and $74.55 \%$ among vocational/technical high school teachers.

Views about the Impacts of Mobile Phone Bans or Restrictions on Educational Outcomes

Of the 424 teachers participating in the study, 266 stated that there were bans or restrictions on the use of mobile phones by students at their school, and 158 of them stated that there were no bans or restrictions. Another issue that is curious within the scope of this research is the impacts of mobile phone bans or restrictions on the educational outcomes. For this purpose, participants' opinions in two separate groups (G1= Ban or restrictions; G2= No ban or restrictions) were analyzed and reported in Table 3.

Table 3. Chi-Square test results regarding the impacts of mobile phone bans or restrictions on educational outcomes

\begin{tabular}{|c|c|c|c|c|c|c|c|}
\hline Items & Groups* & Options & $f$ & $\%$ & $\chi^{2}$ & sd & $\mathrm{p}$ \\
\hline [Bans or restrictions on & \multirow[t]{3}{*}{ G1/G2 } & Yes & $229 / 103$ & $86.09 / 65.19$ & \multirow[t]{3}{*}{32.39} & \multirow[t]{3}{*}{2} & \multirow[t]{3}{*}{.000} \\
\hline students' use of mobile phones] & & No & $6 / 23$ & $2.26 / 14.56$ & & & \\
\hline $\begin{array}{l}\text { contributes positively to build } \\
\text { the classroom discipline. }\end{array}$ & & Undecided & $31 / 32$ & $11.65 / 20.25$ & & & \\
\hline [...] contributes positively to & \multirow[t]{3}{*}{ G1/G2 } & Yes & $210 / 98$ & $78.95 / 62.03$ & \multirow[t]{3}{*}{18.17} & \multirow[t]{3}{*}{2} & \multirow[t]{3}{*}{.000} \\
\hline students' concentration on their & & No & $20 / 32$ & $7.52 / 20.25$ & & & \\
\hline lessons. & & Undecided & $36 / 28$ & $13.53 / 17.72$ & & & \\
\hline \multirow{3}{*}{$\begin{array}{l}{[\ldots] \text { contributes positively to }} \\
\text { the academic success of } \\
\text { students. }\end{array}$} & \multirow[t]{3}{*}{ G1/G2 } & Yes & $184 / 69$ & $69.17 / 43.67$ & \multirow[t]{3}{*}{43.68} & \multirow[t]{3}{*}{2} & \multirow[t]{3}{*}{.000} \\
\hline & & No & 19/47 & $7.14 / 29.75$ & & & \\
\hline & & Undecided & $63 / 42$ & $23.68 / 26.58$ & & & \\
\hline \multirow[t]{3}{*}[\ldots]{ prevents cyberloafing. } & \multirow[t]{3}{*}{ G1/G2 } & Yes & $183 / 94$ & $68.80 / 59.49$ & \multirow[t]{3}{*}{6.95} & \multirow[t]{3}{*}{2} & \multirow[t]{3}{*}{.031} \\
\hline & & No & $44 / 43$ & $16.54 / 27.22$ & & & \\
\hline & & Undecided & $39 / 21$ & $14.66 / 13.29$ & & & \\
\hline \multirow{3}{*}{$\begin{array}{l}{[\ldots] \text { prevents behaviors such as }} \\
\text { cyberbullying from occurring. }\end{array}$} & \multirow[t]{3}{*}{ G1/G2 } & Yes & $131 / 54$ & $49.25 / 34.18$ & \multirow[t]{3}{*}{9.79} & \multirow[t]{3}{*}{2} & \multirow[t]{3}{*}{.007} \\
\hline & & No & $87 / 72$ & $32.71 / 45.57$ & & & \\
\hline & & Undecided & $48 / 32$ & $18.05 / 20.25$ & & & \\
\hline \multirow{3}{*}{$\begin{array}{l}{[\ldots] \text { pushes students to break }} \\
\text { the rules. }\end{array}$} & \multirow[t]{3}{*}{ G1/G2 } & Yes & $81 / 71$ & $30.45 / 44.94$ & \multirow[t]{3}{*}{13.05} & \multirow[t]{3}{*}{2} & \multirow[t]{3}{*}{.001} \\
\hline & & No & $114 / 42$ & $42.86 / 26.58$ & & & \\
\hline & & Undecided & $71 / 45$ & $26.69 / 28.48$ & & & \\
\hline
\end{tabular}

${ }^{*} \mathrm{G} 1=$ Ban or restrictions; $\mathrm{G} 2=$ No ban or restrictions

According to the table, building the classroom discipline $(\chi 2=32.39, \mathrm{sd}=2, \mathrm{p}<.01)$, helping students concentrate on the lesson $(\chi 2=18.17, \mathrm{sd}=2, \mathrm{p}<.01)$, contributing positively to their academic achievement $(\chi 2=43.68, \mathrm{sd}=2, \mathrm{p}<.01)$ were found to differ significantly. 
Majority of the teachers expressed a positive opinion that mobile phone bans or restrictions will contribute to students in terms of lesson discipline and concentration. Similarly, the majority of the participants in the G1 group (69.17\%), in which there are bans or restrictions, stated that this situation had a positive effect on the academic success of the students. On the other hand, it was determined that the opinions of the teachers in the G2 group on the expression of academic achievement are close to each other based on options. Regarding this statement, $43.67 \%$ of the participants stated "Yes", 29.75\% "No" and 26.58\% "Undecided". It is striking that the rate of undecided participants in both groups about academic achievement is close to each other ( $\mathrm{G} 1=23.68 \%, \mathrm{G} 2=26.58 \%$ ). It was figured out that the opinions of the teachers in both groups regarding the expressions of preventing behaviors such as cyberloafing $(\chi 2=6.95, \mathrm{sd}=2, \mathrm{p}<.05)$ and cyberbullying $(\chi 2=9.79, \mathrm{sd}=2, \mathrm{p}<.01)$ and pushing students to violate the rules $(\chi 2=13.05, \mathrm{sd}=2, \mathrm{p}<.05)$ showed a significant difference. The vast majority of participants expressed positive opinion that mobile phone bans or restrictions prevent students from using the Internet for unrelated work during class hours, in other words, cyberloafing. However, it is seen that participants have different views that bans or restrictions on mobile phone use in schools prevent behaviors such as cyberbullying and push students to break the rules. In both groups, it is seen that the total rate of those who disagree with their views that they prevented behaviors such as cyberbullying and pushed students to violate the rules or stated that they were indecisive was higher than the rate of participants agreeing to these statements.

Views Regarding Whether the Mobile Phone is a Need for Students

Countries around the world exhibit different practices regarding the use of mobile phones by students in schools. It also happens that decisions taken depending on the terms and conditions change over time. For example, Japanese government first banned the use of mobile phones by students at schools in 2009. However, this ban was lifted in 2018. Two factors stand out in making this decision in Japan. These are the widespread use of mobile phones among students today and the cases of accessing students via mobile phones in emergencies due to security concerns such as natural disasters. Deloitte (2019) also stated that mobile phones have reached the status of indispensable products for individuals. As can be seen, it is understood that whether the mobile phone is a need or not is considered as an important criterion in the decisions to be taken whether the mobile phone should be used in 
schools. In this context, whether the mobile phone is a need for students and whether these views change according to different education levels were examined.

Table 4. Chi-Square test results regarding whether the mobile phone is a need for students

\begin{tabular}{lccccccc}
\hline \multicolumn{1}{c}{ Item } & Groups* $^{*}$ & Options & $\mathbf{f}$ & $\%$ & $\chi^{2}$ & sd & $\mathbf{p}$ \\
\hline Mobile phone is a need for & G1/G2 & Yes & $92 / 68$ & $34.59 / 43.04$ & 7.32 & 2 & .026 \\
students. & & No & $116 / 48$ & $43.61 / 30.38$ & & & \\
& & Undecided & $58 / 42$ & $21.80 / 26.58$ & & & \\
\hline
\end{tabular}

${ }^{*} \mathrm{G} 1=$ Ban or restrictions; $\mathrm{G} 2=$ No ban or restrictions

In Table 4, the difference observed in the opinions of the participants regarding this statement was found to be significant $(\chi 2=7.32$, $s d=2, p<.05)$. While $34.59 \%$ of the teachers in the G1 group stated that mobile phones are a need for students, this rate is $43.04 \%$ among the participants in the G2 group. Almost half of the participants $(43.61 \%)$ in the G1 group stated that mobile phones are not a need for students. The results of the chi-square test regarding whether the opinions of the teachers differ according to the grade level are given in Table 5.

Table 5. Chi-Square test results regarding whether the mobile phone is a need for students according to grade level

\begin{tabular}{|c|c|c|c|c|c|c|c|c|}
\hline \multirow[b]{2}{*}{ Item } & \multirow[b]{2}{*}{ Groups } & \multicolumn{4}{|c|}{ Grade Level } & \multirow[b]{2}{*}{$\chi^{2}$} & \multirow[b]{2}{*}{ sd } & \multirow[b]{2}{*}{$\mathrm{p}$} \\
\hline & & Options & $\begin{array}{l}\text { Secondary } \\
\text { School }\end{array}$ & $\begin{array}{l}\text { High } \\
\text { School }\end{array}$ & $\begin{array}{c}\text { Vocational - } \\
\text { Technical } \\
\text { High School }\end{array}$ & & & \\
\hline \multirow{6}{*}{$\begin{array}{l}\text { Mobile phone } \\
\text { is a need for } \\
\text { students. }\end{array}$} & G1 & Yes & $53 / 26.37$ & $23 / 53.49$ & $16 / 72.73$ & 29.67 & 4 & .000 \\
\hline & & No & $103 / 51.24$ & $10 / 23.26$ & $3 / 13.64$ & & & \\
\hline & & Undecided & $45 / 22.39$ & $10 / 23.26$ & 3/13.64 & & & \\
\hline & G2 & Yes & $33 / 36.67$ & $21 / 60.00$ & $14 / 42.42$ & 9.81 & 4 & .044 \\
\hline & & No & $31 / 34.44$ & $4 / 11.43$ & $13 / 39.39$ & & & \\
\hline & & Undecided & $26 / 28.89$ & $10 / 28.57$ & $6 / 18.18$ & & & \\
\hline
\end{tabular}

${ }^{*} \mathrm{G} 1=$ Ban or restrictions; G2= No ban or restrictions

As can be seen in the table, a significant difference was observed in the opinions of the participants in both groups regarding whether the mobile phone is a need for the students or not according to their grade level $(\chi 2=29.67, \mathrm{sd}=4, \mathrm{p}<.01 ; \chi 2=9.81, \mathrm{sd}=4, \mathrm{p}<.05)$. It appears that there is a significant relationship between grade level and teachers' opinions. Among the participants in the G1 group, the rate of those who expressed a positive opinion at the "Secondary School" level was 26.37\%, while this rate was 53.49\% for "High School" and 72.73\% for "Vocational/Technical High School". The rate of those who expressed a positive opinion in the G2 group was 36.67\% in the "Secondary School" level, 60.00\% in the "High School" level, and 42.42\% in the "Vocational/Technical High School". 
Views on Education and Guidance Activities on Mobile Phone Use in Schools

When we look at the practices about banning mobile phones in schools, it is seen that countries have taken different approaches based on grade level. However, there is a common similarity between all these different practices. Schools draw up guidelines and inform students about rules. In this context, we examined whether education and guidance activities regarding the effective use of mobile phones are carried out in schools. We also analyzed differences between grade levels.

Table 6. Chi-Square test results on education and guidance activities on cell phone use in schools

\begin{tabular}{lccccccc}
\hline \multicolumn{1}{c}{ Item } & Groups $^{*}$ & Options & $\mathbf{f}$ & $\mathbf{\%}$ & $\chi^{2}$ & sd & p \\
\hline In our school, education and & G1/G2 & Yes & $46 / 19$ & $17.29 / 12.03$ & 3.99 & 2 & .136 \\
guidance activities regarding the & & No & $196 / 117$ & $73.68 / 74.05$ & & & \\
effective use of mobile phones & & Undecided & $24 / 22$ & $9.02 / 13.92$ & & & \\
are carried out. & & & & & & & \\
\hline
\end{tabular}

${ }^{*} \mathrm{G} 1=$ Ban or restrictions; $\mathrm{G} 2=$ No ban or restrictions

As can be seen in Table 6, it was found that the difference observed in teachers' opinions about whether education and guidance activities on mobile phone use were carried out at school was not significant $(\chi 2=3.99, \mathrm{sd}=2, \mathrm{p}>.05)$. Most participants expressed that there was no education and guidance activities on effective use of mobile phones at the schools they work (G1=73.68\%, G2=74.05\%). Among the participants in the G1 group, the rate of those who stated that there were education and guidance activities was $17.29 \%$, while this rate was $12.03 \%$ for G2 group.

The results of the chi-square test regarding whether the views of the participants differ according to the grade level are given in Table 7. Since the expected value for the G2 group is less than 5 , the number of pores exceeds $20 \%$ and it is not possible to join or increase the number of participants, the frequency and percentage values for this group are given in the following table.

Table 7. Chi-Square test results regarding education and guidance activities on mobile phone use in schools according to grade level

\begin{tabular}{|c|c|c|c|c|c|c|c|c|}
\hline \multirow[b]{2}{*}{ Item } & \multirow[b]{2}{*}{ Groups } & \multicolumn{4}{|c|}{ Grade Level } & \multirow[b]{2}{*}{$\chi^{2}$} & \multirow[b]{2}{*}{ sd } & \multirow[b]{2}{*}{$\mathrm{p}$} \\
\hline & & Options & $\begin{array}{c}\text { Secondary } \\
\text { School }\end{array}$ & $\begin{array}{c}\text { High } \\
\text { School }\end{array}$ & $\begin{array}{c}\text { Vocational / } \\
\text { Technical } \\
\text { High School }\end{array}$ & & & \\
\hline \multirow{6}{*}{$\begin{array}{l}\text { In my school, education } \\
\text { and guidance activities } \\
\text { regarding the effective } \\
\text { use of mobile phones are } \\
\text { carried out. }\end{array}$} & \multirow[t]{3}{*}{ G1 } & Yes & $26 / 12.94$ & $15 / 34.88$ & $5 / 22.73$ & \multirow[t]{3}{*}{15.54} & \multirow[t]{3}{*}{4} & \multirow[t]{3}{*}{.004} \\
\hline & & No & $159 / 79.10$ & $22 / 51.10$ & $15 / 68.18$ & & & \\
\hline & & Undecided & $16 / 7.96$ & 6/13.95 & 2/9.09 & & & \\
\hline & \multirow[t]{3}{*}{ G2 } & Yes & $13 / 14.44$ & $4 / 11.43$ & $2 / 6.06$ & \multirow[t]{3}{*}{-} & \multirow[t]{3}{*}{-} & \multirow[t]{3}{*}{-} \\
\hline & & No & 64/71.11 & $26 / 74.29$ & $27 / 81.82$ & & & \\
\hline & & Undecided & $13 / 14.44$ & $5 / 14.29$ & $4 / 12.12$ & & & \\
\hline
\end{tabular}


As can be seen in the table, there is a significant difference in the views of participants according to the grade level $(\chi 2=15.54, \mathrm{sd}=4, \mathrm{p}<.01)$. It appears that there is a significant relationship between grade level and teachers' views. Among the participants in the G1 group, the rate of those who expressed a positive opinion at the "Secondary School" level that education and guidance activities are carried out in their school is $12.94 \%$, while this rate is $34.88 \%$ for "High School" and 22.73\% for "Vocational/Technical High School". In the G2 group, the rate of those who expressed a positive opinion regarding the effective use of mobile phones in their school is $14.44 \%$ at the "Secondary School" level, $11.43 \%$ at the "High School" level, and 6.06\% in the "Vocational/Technical High School".

\section{Discussion}

In this study, ICT teachers' views on their students' use of mobile phones at schools, which has been a hotly debated issue both in Turkey and the world, were tried to be determined. In addition to guiding their students in improving their technology literacy, ICT teachers support their colleagues in developing their techno-pedagogical skills. In this respect, the target group of the study was thought to provide a rich insight to the students' use of mobile phones at schools. To this end, participants' preferred means to access information and their use of mobile phones to communicate so that ICT teachers' personal and professional mobile phone use habits could be determined. Then, through the main global headlines, ICT teachers' views on the reflections for education of bans or restrictions on mobile phone use at schools were examined based on their professional knowledge, field proficiency, and experience.

Findings of the study showed that the majority of teachers at both state and private schools at all education levels prefer mobile phones and computers more frequently than other means to access any information they might need. Moreover, almost all of the participants indicated that they use mobile phones to communicate with their colleagues. Similarly, most of the teachers said that they use mobile phones to communicate with the parents. It was also determined that teachers' views are similar whether they work at a state or a private school. However, it was seen that there are different views when it comes to mobile phone use to communicate with students. It is notable that teachers are almost divided into two in terms of using mobile phones to communicate with their students. Based on school type, when the undecided ones are added to the number of participants who gave 
a negative answer, most of the participants said they do not use their mobile phones to communicate with students. All these findings point at the fact that mobile phones have become indispensable tools for teachers which they use in their personal and professional lives both for accessing information and for communication.

Another question for which an answer was sought in this study was the impacts of mobile phone bans on educational outcomes. In this respect, participants' views were examined in two groups where there are no bans or restrictions in one and certain bans and restrictions in the other. Findings of the study showed that the views of teachers in both these groups vary significantly for the expressions providing class discipline, helping students concentrate on the lesson, contributing positively to students' academic success. Looking at the percentage ratio, the number of people who gave a positive response especially to the expressions of class discipline and lesson concentration is notably high in both groups. This point at the fact that teachers at whose schools there are no bans or restrictions also lean towards bringing bans or restrictions to students' mobile phone use at schools in order to eliminate or minimize factors that disrupt the teaching process and prevent distraction. Similarly, Gao, Yan, Zhao, Pan, and Mo (2014) suggest that an important motivation at the center of school policies concerning mobile phone use is minimizing distraction and disruption to students' learning processes. The effects of mobile phone bans on students' academic success are another highly debated issue in literature. Most of the participants in G1 expressed that the bans or restrictions of mobile phone use has a positive effect on students' academic success. On the other hand, there are differences of opinion among the participants in G2. Teachers in both groups have different opinions concerning the effect on academic success. On this finding, a study in England which examined the effect of mobile phone use restrictions at schools on student productivity, it was observed that banning mobile phones have quite different effects on different groups of students. It was determined that mobile phone bans had the highest positive effect on the learning outcomes of low-achieving students; it had no significant effect on high-achieving students. Findings of the study show that low-achieving students are affected more by the presence of their phones and get distracted more easily; high-achieving students can concentrate in class whether they have their phones with them or not. Researchers underline that mobile phone use in classes should not be disregarded (Beland \& Murphy, 2016). In a similar study by 
Kessel, Hardardottir, and Tyrefors (2020) in Sweden, it was determined that banning mobile phones have no effect on student performance.

Within the scope of the study, participants' views on whether mobile phone bans or restrictions at schools would prevent students from using the Internet at class hours for irrelevant matters (cyberloafing) and whether they would prevent inappropriate and undesired behavior coming into existence through IT tools (cyberbullying) were examined. It was found out that the views of participants in both groups varied significantly. Most of the teachers in groups G1 and G2 indicated that bans or restrictions would prevent cyberloafing. It is evident that the main motivation at the center of the teachers' views, just like in ensuring discipline in class and helping students concentrate, is the desire to minimize cyberloafing. On the other hand, there was no consensus and participants had different opinions when it comes to expressions about cyberbullying and disobeying the rules.

As mentioned before, findings of this study put forth that mobile phones have become an indispensable tool for teachers which they use in their personal and professional lives both for accessing information and for communication. Nevertheless, one of the rather surprising findings of this study is that teachers' views on the merits of mobile phones usage for students are strikingly different even though they use mobile phones as an integral part of their own lives. However, one of the reasons effective on the decision-making processes in Japan in the abolishing of bans in 2018, which were implemented in 2009, is the students' widespread mobile phone use. According to the 2020 data of "Survey on Household Use of Information Technologies," mobile phone use percentage of 16-24-year-old individuals is 92.4\% (TurkStat, 2020). There is no consensus among parents in Turkey as to when is the best time for their kids to own a mobile phone. However, in a study conducted by Dinleyici, Carman, Ozturk, and Sahin-Dagli (2016), 59.8\% of parents indicated that $12-17$ is the most appropriate time to buy a mobile phone for their kids, while $19.5 \%$ said that $6-11$ is the most appropriate time to do so. In a study conducted with the participation of children between the aged 9-16 in seven countries in Europe, it was determined that $46 \%$ of the children own a mobile phone (Mascheroni \& Ólafsson, 2015). Evidently, it is not a distant prediction to claim that mobile phones will be indispensable for children just as they are for adults. Indeed, it can even be presumed that they will become a necessity rather than a need with the more widespread use of new technologies such as web 2.0 tools, online exams, virtual schools, blended learning, and BYOD policies which promotes greater participation. 
The most striking finding of this study is the lack of education and guidance activities for the effective use of mobile phones in many of the schools, independent of the existence of bans or restrictions. However, in many countries, rules and regulations about mobile phone use are left to schools' discretions, and schools are asked to inform their students on the issue. This study puts forth an important conclusion that schools in Turkey should focus their attention to education and guidance activities.

It is evident that countries all over the world have given up on taking blanket decisions about mobile phone use; rather they leave it to schools to make the necessary decisions. Regulation on Secondary Education published on September 5, 2019, is the most comprehensive and current text in Turkey on the use of mobile phones. According to the Regulation, like the global tendency on the issue, rules and regulations on mobile phone use at schools are left to the decision of the board of teachers. The board includes the principal of the institution as the chair, the vice principals, teachers, experts, and education personnel; it shoulders an important responsibility. It would be appropriate for the board to follow a data-based decision-making process on the use of mobile phones at schools, which is an issue that interests not only the school or the teachers but also the students, parents, and other stakeholders. Mobile phones have become indispensable tools for not only the adults but also for children in today's world in which digital technologies are inseparably interconnected with the teaching processes. It should be kept in mind that education is a dynamic process, and the most important pillar is the students. Just like the Japanese example, all countries should continuously monitor and evaluate their students' needs, interests, and expectations based on the ever-changing conditions. In a research realized in Australia, which is considered the first national public opinion study on digital education, it was indicated that the issue of limiting mobile phone use at schools should be tackled carefully. It was reported that there is no consistent public support for completely banning mobile phone use at schools; the public leans more towards limitation than banning. Emphasizing that it should be dealt with individually at school level, the report suggested that easy-to-understand and clear advice policies concerning the use of mobile phones should be developed (Selwyn, 2019). 


\section{Limitations and Recommendations for Future Research}

While this study presents a large perspective on ICT teachers' views on the bans or restrictions of mobile phone use in school, it has some limitations. Firstly, participants of the study involved ICT teachers from secondary school, high school and vocational/technical high school levels. There are considerably fewer high school and vocational/technical high school teachers than secondary school teachers, which limits the generalizability of the study. It is quite possible that the views of a larger population of ICT teachers from different grade levels would differ. Additionally, studies to be conducted with the participation of other stakeholders (school administrators, branch teachers, parents, etc.) in the future would provide richer data for such a significant matter. Secondly, this study relied on self-report survey data. It is also possible to design mixed method studies with large sample sizes. Moreover, considering regional developmental differences in Turkey, future researches at schools that have or do not have bans/restrictions are needed. Thus, the pedagogical consequences and effects of bans and restrictions can be much better understood; understanding what kind of procedures and principles are determined and implemented on a school basis will also help improve school policy standards.

Acknowledgement

An earlier version of this paper was presented at the $28^{\text {th }}$ International Conference on Educational Sciences, Ankara-Turkey (April 25-28, 2019). The data used in this study was confirmed by the researchers that it belongs to the years before 2020.

Author Contribution Statement

Turgay ALAKURT: Conceptualization, methodology, implementation, data analysis, reviewwriting and editing.

Burcu YILMAZ: Conceptualization, methodology, implementation, consultancy and control preliminary draft writing and editing.

\section{References}

Akıncı, A., Kurtoğlu, M., \& Seferoğlu, S. S. (2012, February). Bir teknoloji politikası olarak FATIH projesinin başarılı olması için yapılması gerekenler: Bir durum analizi çalışması [How can FATIH project achieve its goals? A situation analysis study]. Paper presented the XIV. Akademik Bilişim Conference. Uşak, Turkey. 
Attewell, J. (2015). BYOD bring your own device: A guide for school leaders. Brussels: European Schoolnet's Interactive Classroom Working Group.

Baker, W. M., Lusk, E. J., \& Neuhauser, K. L. (2012). On the use of cell phones and other devices in the classroom: Evidence from a survey of faculty and students. Journal of Education for Business, 87(5), 275-289.

Beland, L. P., \& Murphy, R. (2016). Ill communication: Technology, distraction \& student performance. Labour Economics, 41, 61-76. https://doi.org/10.1016/j.labeco.2016.04.004

Büyüköztürk, Ş. (2005). Anket geliştirme [Questionnaire development]. Türkiye Eğitim Bilimleri Dergisi, 3(2), 133-151.

Calabuig, R. C., \& Palacín, A. F. (2016). mSchools programme. A new way of teaching and learning. Journal of the World Federation of Associations for Teacher Education, 1(3a),70-80.

Campbell, S. W. (2007). Perceptions of mobile phones in college classrooms: Ringing, cheating, and classroom policies. Communication Education, 55, 280-294.

Creswell, J. W. (2013). Research design: Qualitative, quantitative, and mixed methods approaches. Thousand Oaks, CA: Sage Publications, Incorporated.

Deloitte (2019). Global mobil kullanıcı anketi 2019: Türkiye yönetici özeti [Global mobile consumer survey 2019: Turkey executive summary]. Retrieved November 03, 2020, from https://www2.deloitte.com/content/dam/Deloitte/tr/ Documents/technologymedia-telecommunications/GMCS-2019-web.pdf

Dinleyici, M., Carman, K. B., Ozturk, E., \& Sahin-Dagli, F. (2016). Media use by children, and parents' views on children's media usage. Interactive Journal of Medical Research, 5(2), e18. doi: 10.2196/ijmr.5668

Doğan, D., Çınar, M., \& Seferoğlu, S. S. (2016). “One Laptop per Child” projects and FATIH project: A comparative examination. SDU International Journal of Educational Studies, $3(1), 1-26$.

Esmeray, A. (2018). Bilişim teknolojisindeki gelişmelerin muhasebe denetimine katkısı [Contribution to accounting auditing to developments in computer technology]. Muhasebe Bilim Dünyası Dergisi, 20, 294-309.

Gao, Q., Yan, Z., Zhao, C., Pan, Y., \& Mo, L. (2014). To ban or not to ban: Differences in mobile phone policies at elementary, middle, and high schools. Computers in Human Behavior, 38, 25-32. https://doi.org/10.1016/j.chb.2014.05.011

Kates, A. W., Wu, H., \& Corny, C. L. (2018). The effects of mobile phone use on academic performance: A meta-analysis. Computers \& Education, 127, 107-112.

Kessel, D., Hardardottir, H. L., \& Tyrefors, B. (2020). The impact of banning mobile phones in Swedish secondary schools. Economics of Education Review, 77, 102009.

Lenhart, A., Ling, R., Campbell, S., \& Purcell, K. (2010). Teens and mobile phones. Washington, DC: Pew Internet \& American Life Project. Retrieved January 20, 2020, from https://www.pewresearch.org/internet/2010/04/20/teens-and-mobile-phones/

Looi, C. K., Sun, D., \& Xie, W. (2015). Exploring students' progression in an inquiry science curriculum enabled by mobile learning. IEEE Transactions on Learning Technologies, 8(1), 43-54. https://doi.org/10.1109/TLT.2014.2376968 
Mascheroni, G., \& Ólafsson, K. (2015). The mobile Internet: Access, use, opportunities and divides among European children. New Media \& Society, 18(8), 1657-1679.

McCoy, B. (2013). Digital distractions in the classroom: Student classroom use of digital devices for nonclass related purposes. Faculty Publications, College of Journalism $\mathcal{E}$ Mass Communications. 71. https://digitalcommons.unl.edu/journalismfacpub/71.

McKinsey \& Company. (2012). Transforming learning through mEducation. Retrieved February 04, 2020, from: https://www.mckinsey.com/ /media/mckinsey/industries/ social\%20sector/our\%20insights/transforming\%20learning\%20through\%20meducatio $\mathrm{n}$ /transforming-learning-through-meducation-final.ashx

Ministry of National Education [MoNE] (2014). Milli eğitim bakanlığı okul öncesi eğitim ve ilköğretim kurumları yönetmeliği [Ministry of national education regulation on preschool education and primary education institutions]. Retrieved May 10, 2020, from http://mevzuat.meb.gov.tr/dosyalar/1703.pdf

Ministry of National Education [MoNE] (2018). Bilişim teknolojileri ve yazılım dersi öğretim programı (Ortaokul 5 ve 6. Siniflar) [Information technologies and software lesson curriculum (Secondary School 5th and 6th Grades)]. Retrieved May 20, 2020, from http://mufredat.meb.gov.tr/ProgramDetay.aspx?PID=374

Ministry of National Education [MoNE] (2019). Milli eğitim bakanlığı ortaöğretim kurumları yönetmeliği [Ministry of national education regulation on secondary education institutions]. Metrieved May 10, 2020, from https://ogm.meb.gov.tr/meb_iys_dosyalar/2019_09/13111232_YONETMELYK.pdf

mSchools (2020). A new way of learning. Retrieved February 15, 2020 from https://mschools.mobileworldcapital.com/our-initiatives/

Mobile phones. (2019, June 26). The new daily. Retrieved from https://thenewdaily.com.au/news/national/2019/06/26/mobile-phones-banned-invictorian-schools/

Mobile phones to be banned. (2019, October 30). The new daily. Retrieved from https://thenewdaily.com.au/news/2019/10/30/mobile-phones-ban-wa/

O'Bannon, B. W., \& Thomas, K. M. (2015). Mobile phones in the classroom: Preservice teachers answer the call. Computers $\mathcal{E}$ Education, 85, 110-122.

Purcell, K., Heaps, A., Buchanan, J., \& Friedrich, L. (2013). How teachers are using technology at home and in their classrooms. Washington, DC: Pew Research Center's Internet \& American Life Project. Retrieved May 10, 2020, from https://www.pewresearch.org/internet/wp-content/uploads/sites/9/media/Files/ Reports/2013/PIP_TeachersandTechnologywithmethodology_PDF.pdf

Selwyn, N. (2019). Digital lessons? Public opinions on the use of digital technologies in Australian schools. Melbourne, Monash University. Retrieved May 10, 2020, from https://apo.org.au/sites/default/files/resource-files/2019-01/apo-nid221076.pdf

Shelton, J. T., Elliott, E. M., Eaves, S. D., \& Exner, A. L. (2009). The distracting effects of a ringing cell phone: An investigation of the laboratory and the classroom setting. Journal of Environmental Psychology, 29(4), 513-521. 
Smith, R. (2018, July 31). France bans smartphones from schools. CNN. Retrieved from https://edition.cnn.com/2018/07/31/europe/france-smartphones-school-ban-intl/index.html

Smith-Stoner M. (2012). Class is about to start: Please turn on your cell phones: 10 uses for cell phones in nursing education. Teaching and Learning in Nursing, 7(2), 42-46.

Steel, C. (2012). Fitting learning into life: Language students' perspectives on benefits of using mobile apps. In M. Brown, M. Hartnett, \& T. Stewart (Eds.), Ascilite 2012: Future challenges, sustainable futures. Wellington: New Zealand.

Sundgren, M. (2017). Blurring time and place in higher education with bring your own device applications: a literature review. Education and Information Technologies, 22, 3081-3119. https://doi.org/10.1007/s10639-017-9576-3

Thomas, K. M, O'Bannon, B. W., \& Bolton, N. (2013). Cell phones in the classroom: Teachers' perspectives of inclusion, benefits, and barriers. Computers in the Schools: Interdisciplinary Journal of Practice, Theory, and Applied Research, 30(4), 295-308.

Tokyo to allow. (2019, June 20). The japan times. Retrieved from https://www.japantimes.co.jp/news/2019/06/20/national/tokyo-allow-students-bringsmartphones-school/

Topu, F. B., \& Göktaş, Y. (2012). Bilişim teknolojileri öğretmenlerinin üstlendikleri roller ve onlardan beklentiler [ICT teachers' assigned roles and expectations from them]. Kuram ve Uygulamada Eğitim Bilimleri, 12(1), 461-478.

TurkStat (2020). Hanehalkı bilişim teknolojileri kullanım araştırması [Information and communication technology (ICT) usage in households and by individuals]. Retrieved January 10, 2021, from https://data.tuik.gov.tr/Kategori/GetKategori?p=bilgiteknolojileri-ve-bilgi-toplumu-102\&dil=1

Walker, R. (2013). “I don't think I would be where I am right now". Pupil perspectives on using mobile devices for learning. Research in Learning Technology, 21.

Winters, N. (2013). Mobile learning in the majority world: A critique of the GSMA position. The SAGE handbook of digital technology research, 10(9781446282229), n27.

Wright, K. (2018, June 20). To ban or not to ban: Should phones be allowed in schools?. BBC news. Retrieved from https://www.bbc.com/news/uk-44546360

Yıldırım, K., Yaşar, Ö., \& Duru, M. (2016). Öğretmen ve öğrenci görüşleri temelinde akıllı telefonların eğitim öğretim ortamlarında kullanılmasının ve etkilerinin incelenmesi [Based on the views of teachers and students analysing the usage of smartphones in teaching and learning environments and effects]. Uluslararası Eğitim Bilim ve Teknoloji Dergisi, 2(2), 72-84. 